\title{
Melatonin reduces apoptotic cells, SOD2 and HSPB1 and improves the in vitro production and quality of bovine blastocysts
}

\author{
TC Marques $^{1}$ | EC da Silva Santos ${ }^{1}$ | TO Diesel $^{1}$ | LO Leme ${ }^{3}$ | CF Martins ${ }^{2}$ | \\ MAN Dode $^{3}$ | BG Alves ${ }^{4}$ | FPH Costa ${ }^{1}$ | EB de Oliveira ${ }^{1}$ | ML Gambarini ${ }^{1}$ (D)
}

\begin{abstract}
${ }^{1}$ Center for Studies and Research in Animal Reproductive Biology, College of Veterinary and Animal Science, Federal University of Goiás, Goiânia, GO, Brazil

${ }^{2}$ Center of Animal Production Systems, Embrapa Cerrados, Brasília, DF, Brazil

${ }^{3}$ Embrapa Genetic Resources and Biotechnology, Laboratory of Animal Reproduction, Brasília, DF, Brazil

${ }^{4}$ Laboratory of Manipulation of Oocytes and Preantral Follicles, Faculty of Veterinary, State University of Ceará, Fortaleza, CE, Brazil

\section{Correspondence}

Maria L. Gambarini, Center for Studies and Research in Animal Reproductive Biology, College of Veterinary and Animal Science, Federal University of Goiás, Goiânia, GO, Brazil

Email: mlgambarini@pq.cnpq.br

\section{Funding information}

Fundacao de Amparo a Pesquisa do Estado de Goias, Grant/Award Number: CH 05/2012; Conselho Nacional de Desenvolvimento Científico e Tecnológico, Grant/Award Number: 448904/2014-4; Empresa Brasileira de Pesquisa Agropecuária, Grant/Award Number: MP1 (01130600104.03.05)
\end{abstract}

\section{Contents}

Effects of adding different concentrations of melatonin $\left(10^{-7}, 10^{-9}\right.$ and $\left.10^{-11} \mathrm{M}\right)$ to maturation (Experiment 1; Control, IVM $+10^{-7}, \mathrm{IVM}+10^{-9}, \mathrm{IVM}+10^{-11}$ ) and culture media (Experiment 2; Control, IVC $+10^{-7}$, IVC $+10^{-9}$, IVC $+10^{-11}$ ) were evaluated on in vitro bovine embryonic development. The optimal concentration of melatonin $\left(10^{-9} \mathrm{M}\right)$ from Experiments 1-2 was tested in both maturation and/or culture media of Experiment 3 (Control, IVM $+10^{-9}$, IVC $+10^{-9}$, IVM/IVC $+10^{-9}$ ). In Experiment 1 , maturated oocytes from Control and IVM $+10^{-9}$ treatments showed increased glutathione content, mitochondrial membrane potential and percentage of Grade I blastocysts (40.6\% and 43\%, respectively). In Experiment 2, an increase in the percentage of Grade I blastocysts was detected in IVC $+10^{-7}$ (43.5\%; $\left.56.7 \%\right)$ and IVC $+10^{-9}$ (47.4\%; 57.4\%). Moreover, a lower number and percentage of apoptotic cells in blastocysts were observed in the IVC $+10^{-9}$ group compared to Control $(3.8 \pm 0.6 ; 3.6 \%$ versus $6.1 \pm 0.6$; 5.3\%). In Experiment 3 , the IVC $+10^{-9}$ treatment increased percentage of Grade I blastocysts with a lower number of apoptotic cells compared to IVM/IVC + $10^{-9}$ group (52.6\%; $3.0 \pm 0.5$ versus $46.0 \% ; 5.4 \pm 1.0$ ). The IVC $+10^{-9}$ treatment also had a higher mRNA expression of antioxidant gene (SOD2) compared to the Control, as well as the heat shock protein (HSPB1) compared to the IVM $+10^{-9}$. Reactive oxygen species production was greater in the IVM/IVC $+10^{-9}$ treatment group. In conclusion, the $10^{-9} \mathrm{M}$ concentration of melatonin and the in vitro production phase in which it is used directly affected embryonic development and quality.

\section{1 | INTRODUCTION}

Reactive oxygen species (ROS) are produced during aerobic metabolism and participate in physiological processes that maintain various biological and reproductive functions, including sperm capacitation, fertilization and gestation (Al-Gubory, Fowler, \& Garrel, 2010; Burton \& Jauniaux, 2011). However, high endogenous ROS concentrations can lead to deleterious effects on cellular functions due to the occurrence of redox imbalance (Takahashi, 2012). Conversely, mammalian cells have highly complex antioxidant systems (enzymatic and non-enzymatic) to protect cells from oxidative damage by "antioxidant" enzymes such as glutathione peroxidase (GSH), catalase and superoxide dismutase (SOD) (Crocomo, Marques Fillho, Landin-Alvarenga, \& Bicudo, 2012; Guérin, El Mouatassim, \& Ménézo, 2001).

During in vitro culture, oocytes, sperm and embryos are exposed to high oxygen concentration (Kitagawa, Suzuki, Yoneda, \& Watanabe, 2004). The absence of the intra-oviductal and intra-uterine environment protection reduces the production of antioxidants and a redox imbalance occurs (Guérin et al., 2001; Kitagawa et al., 2004). Consequently, ROS production increases, and there are deleterious 
effects on DNA repair, organization of the mitotic spindle, oocyte maturation and impairs the embryonic development (Agarwal, Said, Bedaiwy, Banerjee, \& Alvarez, 2006). Thus, in order to provide better conditions for either in vitro or in vivo embryonic development, it is important to maintain the balance of the intracellular redox state (Takahashi, 2012).

The analysis of oxidation status has been used as a method to estimate the risk of oxidative damage during the culture of gametes and embryos in both animal models and humans (Gomes-Sobrinho et al., 2011). Therefore, oxidative stress detection with direct or indirect measures such as ROS production, amount of intracellular GSH, DNA damage or gene expression could be used to develop and evaluate strategies to prevent or minimize oxidative dysfunction during embryonic development (Kwak et al., 2012; Mukherjee et al., 2014). Furthermore, the inclusion of antioxidants or free radical scavengers to the maturation (Casao et al., 2010; Tian et al., 2014) and culture medium (Wang et al., 2013, 2014) may reduce oxidative stress and improve conditions for embryonic development.

In the set of antioxidant substances, melatonin ( $\mathrm{N}$-acetyl-5methoxytryptamine) has been the focus of studies for in vitro embryonic development in humans (Eryilmaz et al., 2011; Khan et al., 2015), mice (Ganji, Nabiuni, \& Faraji, 2015; Ren et al., 2015; Wang et al., 2013), sheep (Vázquez, Abecia, Forcada, \& Casao, 2010), pig (Li et al., 2015; Shi et al., 2009), buffalo (Manjunatha, Devaraj, Gupta, Ravindra, \& Nandi, 2009), rabbit (Mehaisen \& Saeed, 2013; Mehaisen et al., 2015) and cattle (Tian et al., 2014; Wang et al., 2014). Melatonin acts directly on ROS, stimulates the activity of endogenous antioxidant enzymes such as SOD, glutathione reductase and catalase and inhibits the activity of pro-oxidant enzymes such as cyclooxygenase (Anisimov et al., 2006; Tan et al., 2015).

Although the effects of melatonin on antioxidant and antiapoptotic activity during in vitro embryonic (IVP) process are well known (Gomes-Sobrinho et al., 2011; Tamura et al., 2012; Tan et al., 2015), we hypothesized that the effects of melatonin depend on the concentration and phase of the IVP procedure when it is added to the medium. Therefore, the aim of this study was to assess the effects of adding different concentrations of melatonin to the maturation and/ or culture medium on in vitro bovine embryonic development. The following endpoints were measured: (i) cleavage and blastocyst rates, (ii) concentrations of glutathione and ROS, (iii) mitochondrial membrane potential, (iv) blastomere apoptosis and (v) the expression of genes related to metabolism, oxidative stress and placentation.

\section{2 | MATERIALS AND METHODS}

\subsection{Oocyte selection and in vitro maturation}

Bovine ovaries of zebu breeds were collected from local slaughterhouses, transported to the laboratory in a saline solution $(0.9 \%)$ at $35^{\circ} \mathrm{C}$ and processed within $4 \mathrm{hr}$. Cumulus-oocyte complexes (COCs; $n=2,767$, five replicates per treatment) were aspirated from follicles between 3 and $8 \mathrm{~mm}$ in diameter and stored in $15 \mathrm{ml}$ conical polystyrene tubes, in a $36^{\circ} \mathrm{C}$ water bath for 10 min before decantation.
For each treatment, groups of 30-35 COCs with a homogeneous cytoplasm and several cell layers were selected (Stojkovic et al., 2001) and cultured for in vitro maturation in TCM-199 with Earle's salts and L-glutamine (Gibco ${ }^{\circledR}$; Invitrogen Co., Grand Island, NY, USA) supplemented with $10 \%$ foetal bovine serum ( $/ \mathrm{v}$ ), $0.2 \mathrm{mM}$ pyruvate, $5 \mathrm{mg} / \mathrm{ml}$ luteinizing hormone (Lutropin- $\mathrm{V}^{\circledR}$; Bioniche Co., Belleville, ON, Canada), $1 \mathrm{mg} / \mathrm{ml}$ follicle-stimulating hormone (Folltropin ${ }^{\circledR}$; Bioniche Co.), $75 \mu \mathrm{g} / \mathrm{ml}$ amikacin and $1 \mathrm{mM}$ cystamine. The COCs were matured in drops $(200 \mu \mathrm{l})$ covered with mineral oil (Corning, NY, USA) for $22-24 \mathrm{hr}$ at $38.5^{\circ} \mathrm{C}$ in $5 \% \mathrm{CO}_{2}$ in air and saturated relative humidity without condensation.

\section{2 | In vitro fertilization}

After the maturation period, the COCs were washed in fertilization medium TALP-FERT (Tyrode's albumin lactate pyruvate (TALP) supplemented with $6 \mathrm{mg} / \mathrm{ml}$ bovine serum albumin (BSA)-fatty acid-free, $0.2 \mathrm{mM}$ pyruvate, $30 \mu \mathrm{g} / \mathrm{ml}$ heparin, $20 \mu \mathrm{M}$ penicillamine, $10 \mu \mathrm{M}$ hypotaurine, $1 \mu \mathrm{M}$ epinephrine and $75 \mathrm{mg} / \mathrm{ml}$ amikacin) and fertilized in drops $(200 \mu l)$ of the same medium.

For in vitro fertilization (IVF), conventional commercial frozen semen from Nellore bull with known and tested in vitro fertility was used. After thawing $\left(35^{\circ} \mathrm{C}\right.$ for $\left.30 \mathrm{~s}\right)$, the sperm cells were obtained after treatment with a $45 \%-90 \%$ Percoll gradient as previously described (Parrish, Krogenaes, \& Susko-Parrish, 1995). Each drop of COCs was fertilized with a final concentration of $1 \times 10^{6}$ spermatozoa $/ \mathrm{ml}$. The sperm cells were co-incubated with oocytes for $18 \mathrm{hr}$ under the same conditions described for maturation.

\section{3 | In vitro embryo culture}

Presumptive zygotes were denuded partially by repeated pipetting, then washed and transferred into drops (200 $\mu$ l) of modified synthetic oviduct fluid (Holm, Schimidt, Greve, \& Callesen, 1999) supplemented with $2.7 \mathrm{mM}$ myo-inositol, $0.2 \mathrm{mM}$ pyruvate, $2.5 \%$ foetal bovine serum ( $\mathrm{v} / \mathrm{v}), 5 \mathrm{mg} / \mathrm{ml} \mathrm{BSA-fatty}$ acid-free and $75 \mu \mathrm{g}$ / $\mathrm{ml}$ amikacin. Embryo culture was performed for 7 days at $38.5^{\circ} \mathrm{C}$ in $5 \% \mathrm{CO}_{2}$ in air and saturated relative humidity without condensation. After $72 \mathrm{hr}$ of culture, the cleavage rate was assessed and half of the culture medium in each drop was replaced with fresh medium. Structures were considered cleaved when the cellular division with at least 2-4 cells was present. The morphological quality of the embryos was measured according to International Embryo Transfer Society (IETS) guidelines. According to IETS, the quality of the embryos is classified in Grade 1 to 4 (1-excellent/good, 2-regular, 3-poor, 4-unviable). Embryos are graded regarding the number of physical characteristics including shape, colour and density of cytoplasm or inner cell mass, number and compactness of cells, area of perivitelline space, number of extruded or degenerate cells and frequency and size of cytoplasmic vacuoles. The per cent blastocyst at day 7 (D7) was evaluated, where day 0 (DO) is the day of IVF. 


\section{4 | Experimental design}

\subsection{1 | Experiment 1-Effect of melatonin added to maturation medium on in vitro bovine embryonic development}

After selection, COCs were placed into drops of maturation medium without (Control) or supplemented with different concentrations $\left(10^{-7}, 10^{-9}\right.$ and $\left.10^{-11} \mathrm{M}\right)$ of melatonin (Sigma Co., St. Louis, MO USA) represented by the treatments: IVM $+10^{-7}, I V M+10^{-9}$ and IVM $+10^{-11}$, respectively. MMP, ROS and GSH were measured in oocytes after $24 \mathrm{hr}$ of maturation. Also, cleavage, blastocyst formation and quality were assessed.

\subsection{2 | Experiment 2-Effect of melatonin added to culture medium on in vitro bovine embryonic development}

After maturation and fertilization, presumptive zygotes were transferred into drops of culture medium without (Control) or supplemented with different concentrations of melatonin $\left(10^{-7}, 10^{-9}\right.$ and $10^{-11} \mathrm{M}$ ) represented by the treatments IVC $+10^{-7}, \mathrm{IVC}+10^{-9}$ and IVC $+10^{-11}$, respectively. Cleavage, blastocyst formation and quality were evaluated. Moreover, total cell number and number of apoptotic cells in the blastocysts were measured.

\subsection{3 | Experiment 3-Effect of melatonin added to maturation and culture medium on in vitro bovine embryonic development}

After evaluation of embryonic development and analysis of GSH, MMP and apoptosis, the better results from Experiment $1\left(\mathrm{IVM}+10^{-9}\right)$ and Experiment $2\left(\right.$ IVC $\left.+10^{-9}\right)$ were associated with the maturation and culture medium (IVM/IVC $+10^{-9}$ ) and compared to the Control group. Cleavage, blastocyst formation and quality, GSH, ROS, total cell number and cellular apoptosis in blastocysts were evaluated. In addition, embryo viability was analysed by expression of five genes related to metabolism (SLC2A1, SLC2A3), oxidative stress (HSPB1, SOD2) and placentation (KRT8).

\subsection{Intracellular measurement of reactive oxygen species (ROS) and glutathione (GSH)}

Intracellular content of ROS and GSH was measured in denuded oocytes matured in vitro (Experiment 1) and in D7 blastocysts (Experiment 3), as described previously (Park \& Yu, 2013) with some modifications. Briefly, to evaluate ROS and GSH, $10 \mathrm{mM}$ 6-carboxy -2,7-dichlorodihydrofluorescein diacetate (H2DCFDA, Molecular Probes $^{\circledR}$, Eugene, OR) and $10 \mathrm{mM}$ 4-chloromethyl-6,8-difluoro-7-h ydroxycoumarin (Cell Tracker ${ }^{\mathrm{TM}}$ Blue $\mathrm{CMF}_{2} \mathrm{HC}$, Molecular Probes ${ }^{\circledR}$, Eugene, OR) were used, respectively. Oocytes and embryos were washed in $0.1 \%$ polyvinyl alcohol in phosphate-buffered saline (PBSPVA) and incubated concurrently with both probes at $38.5^{\circ} \mathrm{C}$ in the dark for $30 \mathrm{~min}$. After incubation, the oocytes and embryos were washed with PBS-PVA, placed onto glass slides with ProLong ${ }^{\circledR}$ Gold (Molecular Probes, Eugene, OR) and cover-slipped. Then, the slides were brought to the epifluorescence microscope (Olympus BX43, Tokyo, Japan). First, under the $460 \mathrm{~nm}$ wavelength filter for observation and image capture of ROS. Immediately afterwards, the same procedure was performed for GSH with a 370-nm wavelength filter.

Images were obtained using a camera (Olympus SC30, Tokyo, Japan) coupled to the epifluorescence microscope and saved in a TIFF format. The fluorescence intensities of the oocytes and embryos were analysed individually using Image J software (version 1.46; National Institutes of Health, Bethesda, MD) and normalized to the Control group. The relative fluorescence intensity was considered directly proportional to ROS and GSH concentrations.

\section{6 | Measurement of mitochondrial membrane potential (MMP)}

In Experiment 1, the mitochondrial membrane potential of the oocytes was measured after $24 \mathrm{hr}$ of in vitro maturation using a fluorescent indicator for mitochondrial activity (thiol-chloromethyl), according to the method previously described (Santos, Sato, Lucia, \& Iwata, 2013). Oocytes were denuded, washed in PBS-PVA and kept at $38.5^{\circ} \mathrm{C}$ for 30 min in PBS-PVA with $0.5 \mu \mathrm{M} \mathrm{C}_{24} \mathrm{H}_{24} \mathrm{Cl}_{2} \mathrm{~N}_{2} \mathrm{O}$ (MitoTracker Orange CMTMRos $^{\circledR}$; Life Technologies Corporation, Carlsbad, CA, USA). Next, oocytes were washed in PBS-PVA, fixed in $3.7 \%$ paraformaldehyde for $24 \mathrm{hr}$ at $4^{\circ} \mathrm{C}$ protected from light. Afterwards, they were washed in PBS-PVA, placed onto glass plates with ProLong ${ }^{\circledR}$ Gold (Molecular Probes, Eugene, OR), cover-slipped and examined under an epifluorescence microscope (Olympus BX43, Tokyo, Japan) with a 550-nm wavelength filter. Images were obtained, and the light intensity emitted by each oocyte was analysed as previously described for ROS and GSH.

\section{7 | Analysis of apoptotic cells}

Blastomere apoptosis was detected using the TUNEL technique (terminal deoxynucleotidyl transferase (TdT)-mediated dUTP nick end labelling), with a commercial In Situ Cell Death Detection kit (Roche, Mannheim, Germany). Experimental groups were prepared according to manufacturer's instructions: treatments, positive Control and negative Control. Blastocysts (D7) were washed in $0.1 \%$ polyvinylpyrrolidone in phosphate-buffered saline (PBS-PVP) and then fixed in $3.7 \%$ paraformaldehyde diluted in PBS-PVP for $1 \mathrm{hr}$ at room temperature. Shortly afterwards, they were incubated in a membrane permeabilization solution (PBS containing $0.5 \%$ Triton X-100 and sodium citrate) for $1 \mathrm{hr}$ at $4^{\circ} \mathrm{C}$. Next, the positive Control group was incubated in a DNAse solution for $1 \mathrm{hr}$ in a humid chamber at $37^{\circ} \mathrm{C}$, while the other groups remained in PBS-PVP on a hot plate at $37^{\circ} \mathrm{C}$. Afterwards, the blastocysts were incubated for the TUNEL reaction (treated and positive groups in the enzyme marker solution [1:9]; negative group in the marker solution only) for $1 \mathrm{hr}$ in a humid chamber at $37^{\circ} \mathrm{C}$ with protection from light. Next, all groups were 
TABLE 1 Specific primers used to amplify gene fragments for quantitative real-time PCR analysis
TABLE 2 In vitro embryonic development and quality maturated with different concentrations of melatonin (Experiment 1)

\begin{tabular}{|c|c|c|c|c|}
\hline Gene & Primer sequence & Size (bp) & $\begin{array}{l}\text { Primer } \\
\text { concentra- } \\
\text { tion (nM) }\end{array}$ & $\begin{array}{l}\text { GenBank Access/ } \\
\text { Reference No. }\end{array}$ \\
\hline \multirow[t]{2}{*}{ GAPDH } & $\begin{array}{l}\text { F: GGC GTG AAC CAC GAG } \\
\text { AAG TAT AA }\end{array}$ & 118 & 300 & NM_001034034.2 \\
\hline & $\begin{array}{l}\text { R: CCC TCC ACG ATG CCA } \\
\text { AAG T }\end{array}$ & & & \\
\hline \multirow[t]{2}{*}{ SLC2A1 } & $\begin{array}{l}\text { F: CAG GAG ATG AAG GAG } \\
\text { GAG AGC }\end{array}$ & 258 & 250 & ВТ029806 \\
\hline & $\begin{array}{l}\text { R: CAC AAA TAG CGA CAC } \\
\text { GAC AGT }\end{array}$ & & & \\
\hline \multirow[t]{2}{*}{ SLC2A3 } & $\begin{array}{l}\text { F: ACT CTT CAC CTG ATT } \\
\text { GGC CTT GGA }\end{array}$ & 145 & 300 & NM_174603.3 \\
\hline & $\begin{array}{l}\text { R: GGC CAA TTT CAA AGA } \\
\text { AGG CCA CGA }\end{array}$ & & & \\
\hline \multirow[t]{2}{*}{ KRT8 } & $\begin{array}{l}\text { F: TGT GAA GAA GAT TGA } \\
\text { GAC CCG CGA }\end{array}$ & 160 & 300 & $\begin{array}{l}\text { X12877 (El-Sayed } \\
\text { et al., 2006) }\end{array}$ \\
\hline & $\begin{array}{l}\text { R: AAA CCT CAG GTC TCC } \\
\text { TGT GCA GAT }\end{array}$ & & & \\
\hline \multirow[t]{2}{*}{ SOD2 } & $\begin{array}{l}\text { F: TTG CTG GAA GCC ATC } \\
\text { AAA CGT GAC }\end{array}$ & 135 & 300 & NM_201527 \\
\hline & $\begin{array}{l}\text { R: AAT CTG TAA GCG TCC } \\
\text { CTG CTC CTT }\end{array}$ & & & \\
\hline \multirow[t]{2}{*}{ HSPB1 } & $\begin{array}{l}\text { F: CTG GAC GTC AAC CAC } \\
\text { TTC }\end{array}$ & 180 & 250 & NM_001025569.1 \\
\hline & $\begin{array}{l}\text { R: GGA CAG AGA GGA GGA } \\
\text { GAC }\end{array}$ & & & \\
\hline
\end{tabular}

GAPDH = glyceraldehyde-3-phosphate dehydrogenase; SLC2A1 = Bos taurus solute carrier family 2 (facilitated glucose transporter), member 1 ; SLC2A3 = Bos taurus solute carrier family 2 (facilitated glucose transporter), member $3 ; \mathrm{KRT} 8=$ keratin 8 ; $\mathrm{SOD} 2=$ Bos taurus superoxide dismutase 2; HSPB1 = Bos taurus heat shock 27 kDa protein 1. F: forward primer; R: reverse primer.

\begin{tabular}{ccccc} 
& & & \multicolumn{2}{l}{ Blastocyst quality (\%) } \\
\cline { 5 - 5 } Treatment & Cleavage (\%) & Blastocyst (\%) & Grade I & Grade II \\
$\begin{array}{c}\text { Control }^{\dagger} \\
(n=254)\end{array}$ & $75.6(192 / 254)^{\mathrm{b}}$ & $39.8(101 / 254)^{\mathrm{a}}$ & $40.6(41 / 101)^{\mathrm{ab}}$ & $38.6(39 / 101)^{\mathrm{b}}$ \\
$\begin{array}{c}\text { IVM }+10^{-7} \\
(n=260)\end{array}$ & $74.6(194 / 260)^{\mathrm{b}}$ & $36.2(94 / 260)^{\mathrm{a}}$ & $27.7(26 / 94)^{\mathrm{b}}$ & $36.2(34 / 94)^{\mathrm{b}}$ \\
$\begin{array}{c}\text { IVM }+10^{-9} \\
(n=253)\end{array}$ & $88.9(225 / 253)^{\mathrm{a}}$ & $42.3(107 / 253)^{\mathrm{a}}$ & $43.0(46 / 107)^{\mathrm{a}}$ & $34.6(37 / 107)^{\mathrm{b}}$ \\
$\begin{array}{c}\text { IVM }+10^{-11} \\
(n=261)\end{array}$ & $83.1(217 / 261)^{\mathrm{a}}$ & $44.4(116 / 261)^{\mathrm{a}}$ & $10.3(12 / 116)^{\mathrm{c}}$ & $69.0(80 / 116)^{\mathrm{a}}$ \\
\hline
\end{tabular}

${ }^{\dagger}$ Number of oocytes subjected to in vitro maturation. Control: medium without melatonin; maturation medium supplemented with $10^{-7}\left(\mathrm{IVM}+10^{-7}\right), 10^{-9}\left(\mathrm{IVM}+10^{-9}\right)$ and $10^{-11} \mathrm{M}\left(\mathrm{IVM}+10^{-11}\right)$ of melatonin. ${ }^{\mathrm{a}, \mathrm{b}, \mathrm{c}}$ Within a column, values without a common superscript differed among treatments $(p<.05)$. incubated in a Hoechst 33342 solution (Invitrogen Corp., Carlsbad, CA) for $10 \mathrm{~min}$, protected from light. ProLong ${ }^{\circledR}$ Gold (Molecular Probes, Eugene, OR) was used to mount the slides and coverslips for observation with an epifluorescence microscope (Olympus BX43, Tokyo, Japan). Between each stage, the groups were washed with three drops of PBS-PVP, remaining for 2 min in the last drop. Nuclei of the TUNEL-positive cells-that is, those that contain fragmented DNA-were visualized under green fluorescence at a wavelength of $450 \mathrm{~nm}$. All nuclei were visualized under blue fluorescence at $365 \mathrm{~nm}$. Nuclei were counted to obtain the total number of cells (TNC, blue) and the number of apoptotic cells (NAC, green) in embryos from each group. 


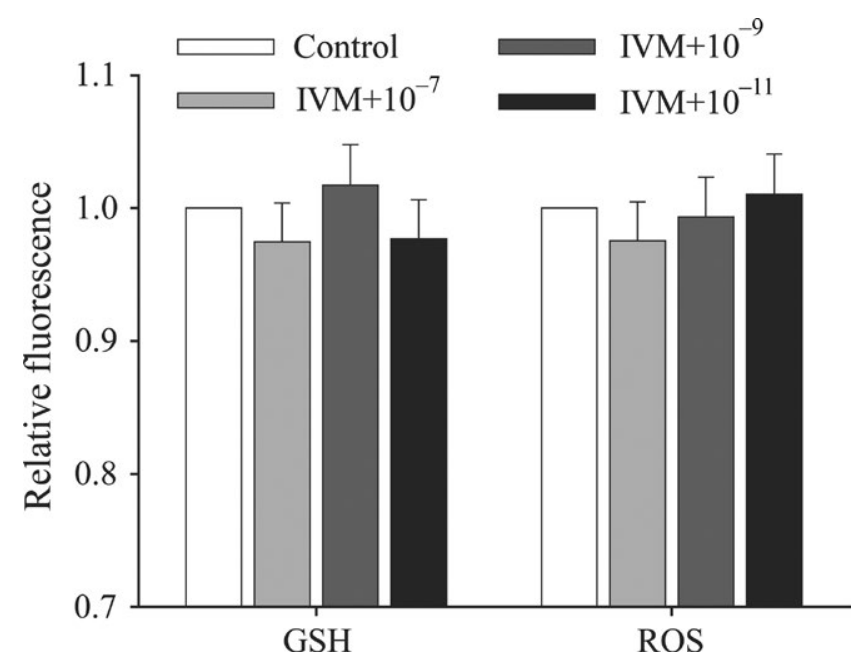

FIGURE 1 Intracellular levels of glutathione (GSH) and reactive oxygen species (ROS) in oocytes $(n=152)$ matured in vitro with different concentrations of melatonin. Control: medium without melatonin; maturation medium supplemented with $10^{-7}\left(\mathrm{IVM}+10^{-7}\right)$, $10^{-9}\left(\mathrm{IVM}+10^{-9}\right)$ and $10^{-11} \mathrm{M}\left(\mathrm{IVM}+10^{-11}\right)$ of melatonin.

Fluorescence intensity in the Control group was defined as 1.0.

$\mathrm{a}, \mathrm{b}, \mathrm{c}$ Within the same parameter evaluated, values without a common letter differed $(p<.001)$

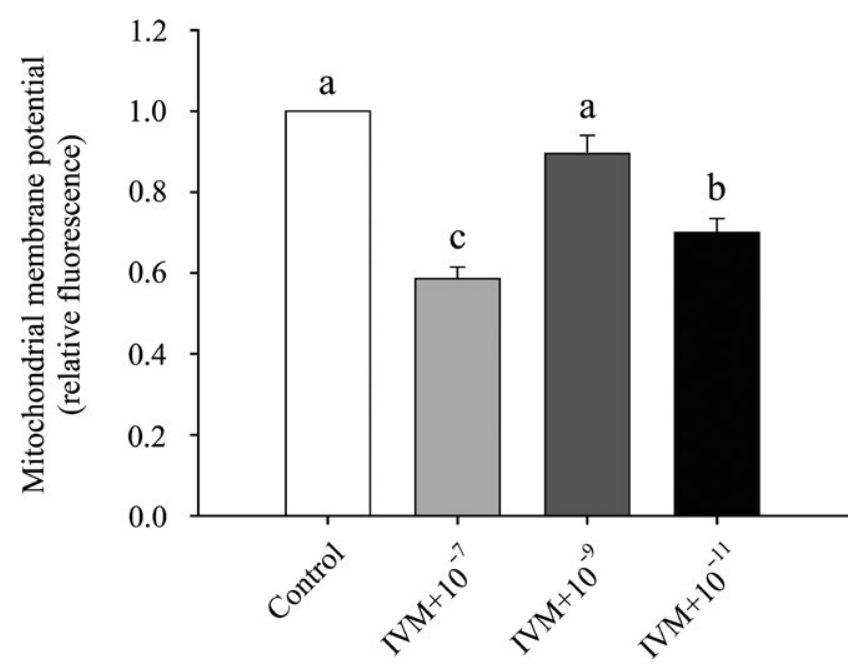

FIGURE 2 Mitochondrial membrane potential (MMP) in oocytes $(n=140)$ matured in vitro with different concentrations of melatonin. Control: medium without melatonin; maturation medium supplemented with $10^{-7}\left(\mathrm{IVM}+10^{-7}\right), 10^{-9}\left(\mathrm{IVM}+10^{-9}\right)$ and $10^{-11} \mathrm{M}$ $\left(\mathrm{IVM}+10^{-11}\right)$ of melatonin. Fluorescence intensity in the Control group was defined as 1.0. ${ }^{\mathrm{a}, \mathrm{b}, \mathrm{c}}$ Values without a common letter differed $(p<.001)$

\section{8 | Sample preparation, RNA extraction and cDNA production}

Blastocysts (D7) were washed in PBS without calcium and magnesium and transferred into $2 \mu \mathrm{l}$ of PBS plus $4 \mu \mathrm{l}$ of RNAlater (Life Technologies Corporation, Carlsbad, CA, USA) into DNAse/RNAsefree polypropylene microtubes. After incubation at $4^{\circ} \mathrm{C}$ for $12 \mathrm{hr}$, they were stored at $-20^{\circ} \mathrm{C}$ until RNA extraction.
Embryo viability was evaluated by the expression of five genes related to metabolism (SLC2A1, SLC2A3), oxidative stress (HSPB1, SOD2) and placentation (KRT8), using quantitative real-time reverse transcription polymerase chain reaction (qRT-PCR). Three pools of 15 blastocysts were used for each treatment.

Total RNA was isolated using an RNeasy Plus Micro Kit (Qiagen ${ }^{\circledR}$, Hilden, Germany) according to manufacturer's instructions. The total amount of isolated RNA was used to synthesize cDNA using a commercial First-Strand cDNA Synthesis kit (Invitrogen)-SuperScript ${ }^{\circledR}$ III $(200 \mathrm{U} / \mu \mathrm{l})$ and oligo-dT primer $(0.5 \mu \mathrm{g} / \mu \mathrm{l})$ to a final volume of $40 \mu \mathrm{l}$. Reactions were performed at $65^{\circ} \mathrm{C}$ for $5 \mathrm{~min}$ and $50^{\circ} \mathrm{C}$ for $50 \mathrm{~min}$, followed by inactivation of the enzyme at $85^{\circ} \mathrm{C}$ for $5 \mathrm{~min}$. The qPCR analysis was performed using the Fast Sybr Green Master Mix (Applied Biosystems). Reactions were optimized to promote the maximum amplification efficiency for each gene (76\%-110\%), calculated using the standard relative curves in the software program 7500 2.0.3 (Applied Biosystems). Each sample was analysed in triplicate, and the specificity of each PCR product was determined through analysis of the melting curve and amplicon size on an agarose gel. Reactions were performed in a final volume of $25 \mu \mathrm{l}$ using a cDNA amount equivalent to 0.5 embryos. The conditions for the PCR reaction were as follows: $95^{\circ} \mathrm{C}$ for $5 \mathrm{~min}, 50$ cycles at $95^{\circ} \mathrm{C}$ for $10 \mathrm{~s}$ and $60^{\circ} \mathrm{C}$ for $30 \mathrm{~s}$. The name, primer sequence and concentration, amplicon size and annealing temperature for each gene are listed in Table 1.

Expression levels of the three constituent genes-glyceraldehyde3 -phosphate dehydrogenase (GAPDH), $\beta$-actin (ACTB) and peptidylprolyl isomerase A (PPIA)-were analysed using geNorm software, which determined that GAPDH was the most stable gene. GAPDH was therefore used as a reference to normalize the data. The relative expression of each gene was calculated using the $\Delta \Delta C_{t}$ method with efficiency correction (Pfaffl, 2001).

\subsection{Statistical analyses}

All statistical analyses were performed using $\mathrm{R}$ software version 3.0.2 (R Core Team, 2014). Data that were not normally distributed by the Shapiro-Wilk test were submitted to natural log transformation. Reactive oxygen species, glutathione, mitochondrial membrane potential and gene expression were analysed among treatments by Kruskal-Wallis test. Total cell number, number of apoptotic cells and mitochondrial membrane potential were compared among treatments by Tukey test. The cleavage and blastocyst rates and blastocyst quality were compared among treatments using the chi-square test. Data are presented as mean ( \pm standard deviation) and percentage. Results were considered significantly different at $p<.05$ (two-sided).

\section{3 | RESULTS}

\section{1 | Experiment 1}

Addition of melatonin to the maturation medium at concentrations of $10^{-9}\left(\mathrm{IVM}+10^{-9}\right)$ and $10^{-11} \mathrm{M}\left(\mathrm{IVM}+10^{-11}\right)$ increased $(p<.05)$ the 
TABLE 3 Effects of different concentrations of melatonin added to culture medium on embryonic development and quality (Experiment 2)

\begin{tabular}{|c|c|c|c|c|}
\hline \multirow[b]{2}{*}{ Treatment } & \multirow[b]{2}{*}{ Cleavage (\%) } & \multirow[b]{2}{*}{ Blastocyst (\%) } & \multicolumn{2}{|c|}{ Blastocyst quality (\%) } \\
\hline & & & Grade I & Grade II \\
\hline $\begin{array}{l}\text { Control }^{\dagger} \\
(n=221)\end{array}$ & $79.6(176 / 221)^{\mathrm{ab}}$ & $37.1(82 / 221)^{b c}$ & $39.9(32 / 82)^{b}$ & $34.1(28 / 82)^{a}$ \\
\hline $\begin{array}{l}\text { IVC + } 10^{-7} \\
(n=223)\end{array}$ & $75.8(169 / 223)^{\mathrm{bc}}$ & $43.5(97 / 223)^{a b}$ & $56.7(55 / 97)^{\mathrm{ac}}$ & $28.9(28 / 97)^{a}$ \\
\hline $\begin{array}{l}\text { IVC }+10^{-9} \\
(n=228)\end{array}$ & $84.2(192 / 228)^{a}$ & $47.4(108 / 228)^{a}$ & $57.4(62 / 108)^{\mathrm{ac}}$ & $27.8(30 / 108)^{a}$ \\
\hline $\begin{array}{l}\text { IVC + } 10^{-11} \\
(n=228)\end{array}$ & $70.6(161 / 228)^{c}$ & $31.1(71 / 228)^{c}$ & $50.7(36 / 71)^{\mathrm{bc}}$ & $35.2(25 / 71)^{a}$ \\
\hline
\end{tabular}

${ }^{\dagger}$ Number of oocytes subjected to in vitro maturation. Control: medium without melatonin; culture medium supplemented with $10^{-7}\left(\right.$ IVC $\left.+10^{-7}\right), 10^{-9}\left(\right.$ IVC $\left.+10^{-9}\right)$ and $10^{-11} \mathrm{M}\left(\right.$ IVC $\left.+10^{-11}\right)$ of melatonin. $\mathrm{a}, \mathrm{b}, \mathrm{c}$ Within a column, values without a common superscript differed among treatments $(p<.05)$.
TABLE 4 Effects of different concentrations of melatonin added to culture medium on the total cell number and apoptotic cells (mean \pm standard deviation) in blastocysts produced in vitro (Experiment 2)

\begin{tabular}{ccc} 
Treatments & Total cell number & $\begin{array}{l}\text { Number of } \\
\text { apoptotic cells (\%) }\end{array}$ \\
$\begin{array}{c}\text { Control } \\
(n=20)\end{array}$ & $115.9 \pm 4.0^{\mathrm{a}}$ & $6.1 \pm 0.6(5.3)^{\mathrm{b}}$ \\
$\begin{array}{c}\text { IVC }+10^{-7} \\
(n=20)\end{array}$ & $115.1 \pm 3.8^{\mathrm{a}}$ & $6.3 \pm 0.5(5.5)^{\mathrm{b}}$ \\
$\begin{array}{c}\text { IVC }+10^{-9} \\
(n=20)\end{array}$ & $103.3 \pm 4.1^{\mathrm{a}}$ & $3.8 \pm 0.6(3.6)^{\mathrm{a}}$ \\
\hline $\begin{array}{c}\text { IVC }+10^{-11} \\
(n=20)\end{array}$ & $111.4 \pm 4.0^{\mathrm{a}}$ & $5.1 \pm 0.6(4.6)^{\mathrm{ab}}$ \\
\hline
\end{tabular}

${ }^{\dagger}$ Number of blastocysts evaluated. Control: medium without melatonin; culture medium supplemented with $10^{-7}\left(\right.$ IVC $\left.+10^{-7}\right), 10^{-9}\left(\right.$ IVC $\left.+10^{-9}\right)$ and $10^{-11} \mathrm{M}$ (IVC $+10^{-11}$ ) of melatonin. ${ }^{a, b}$ Within a column, values without a common superscript differed among treatments $(p<.05)$.

rate of embryonic cleavage, but did not improve the blastocyst formation (Table 2). Also, the percentage of blastocysts Grade I was lower $(p<.05)$ in IVM $+10^{-7}$ and IVM $+10^{-11}$ treatments in comparison with the IVM $+10^{-9}$. Percentage of blastocysts Grade II was higher for the IVM $+10^{-11}$.

The intracellular levels of GSH and ROS in oocytes after in vitro maturation are presented in Figure 1. Oocytes in the IVM $+10^{-9}$ treatment showed an increase in GSH $(p<.001)$, while those in the $\operatorname{IVM}+10^{-7}$ treatment showed a lower amount of ROS $(p<.001)$. In addition, a lower amount of MMP was seen in IVM $+10^{-7}$ and IVM $+10^{-11}$ groups compared to Control and IVM $+10^{-9}$ treatments $(p<.001$; Figure 2$)$.

\section{2 | Experiment 2}

The embryonic development and quality after in vitro culture in medium supplemented with different concentrations of melatonin are shown (Table 3$)$. Greater percentage $(p<.05)$ of cleavage was detected in the IVC $+10^{-9}$ in comparison with IVC $+10^{-7}$ and IVC $+10^{-11}$. Also, IVC $+10^{-9}$ treatment had a higher $(p<.05)$ percentage of blastocysts compared to the Control group. Furthermore, a higher $(p<.05)$ percentage of Grade I blastocysts occurred in the in the IVC $+10^{-7}$ and IVC $+10^{-9}$ treatments compared with Control group.
TABLE 5 Percentage of cleavage, blastocyst formation and quality after the addition of melatonin at $10^{-9} \mathrm{M}$ in different phases of in vitro production (Experiment 3)

\begin{tabular}{lllll} 
& & & \multicolumn{2}{l}{ Blastocyst quality (\%) } \\
\cline { 5 - 5 } Treatment & Cleavage (\%) & Blastocyst (\%) & Grade I & Grade II \\
$\begin{array}{c}\text { Control } \\
(n=216)\end{array}$ & $83.3(180 / 216)^{\mathrm{a}}$ & $41.7(90 / 216)^{\mathrm{b}}$ & $35.6(32 / 90)^{\mathrm{b}}$ & $34.4(31 / 90)^{\mathrm{a}}$ \\
$\begin{array}{c}\text { IVM }^{\dagger}+10^{-9} \\
(n=201)\end{array}$ & $86.6(174 / 201)^{\mathrm{a}}$ & $47.3(95 / 201)^{\mathrm{ab}}$ & $44.2(42 / 95)^{\mathrm{b}}$ & $31.6(30 / 95)^{\mathrm{a}}$ \\
$\begin{array}{c}\text { IVC }+10^{-9} \\
(n=216)\end{array}$ & $82.9(179 / 216)^{\mathrm{a}}$ & $52.8(114 / 216)^{\mathrm{a}}$ & $52.6(60 / 114)^{\mathrm{a}}$ & $28.9(33 / 114)^{\mathrm{a}}$ \\
$\begin{array}{c}\text { IVM/IVC }+10^{-9} \\
(n=206)\end{array}$ & $79.6(164 / 206)^{\mathrm{a}}$ & $42.2(87 / 206)^{\mathrm{b}}$ & $46.0(40 / 87)^{\mathrm{b}}$ & $36.8(32 / 87)^{\mathrm{a}}$ \\
\hline
\end{tabular}

${ }^{\dagger}$ Number of oocytes subjected to in vitro maturation. Control: medium without melatonin; IVM $+10^{-9}$ : maturation medium supplemented with $10^{-9} \mathrm{M}$ of melatonin; IVC $+10^{-9}$ : culture medium supplemented with $10^{-9} \mathrm{M}$ of melatonin; IVM/IVC $+10^{-9}$ : maturation and culture medium supplemented with $10^{-9} \mathrm{M}$ of melatonin. ${ }^{\mathrm{a}, \mathrm{b}}$ Within a column, values without a common superscript differed among treatments $(p<.05)$. 


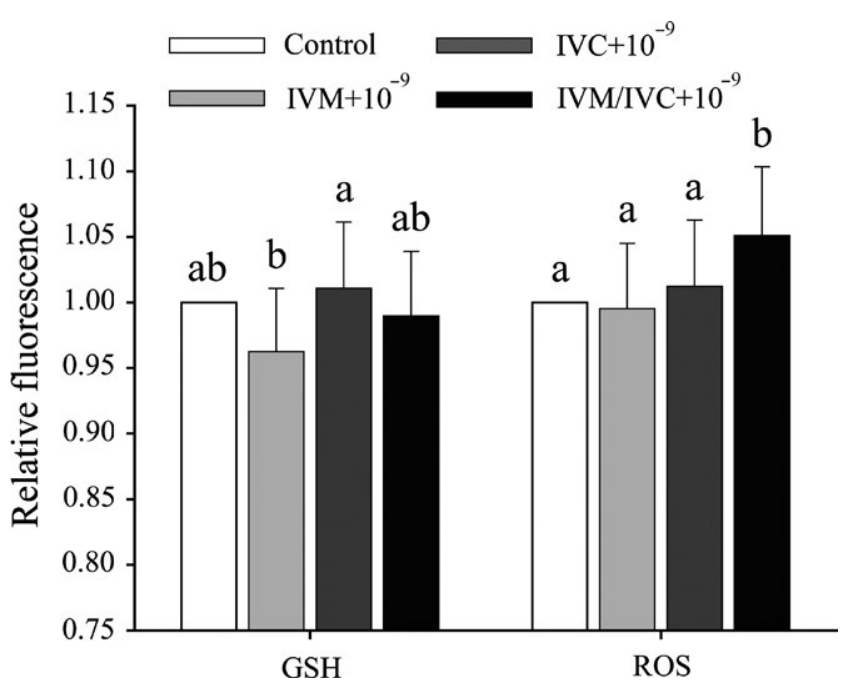

FIGURE 3 Intracellular levels of glutathione (GSH) and reactive oxygen species $(R O S)$ in blastocysts $(n=60)$ after the addition of melatonin at $10^{-9} \mathrm{M}$ in different phases of in vitro production. Control: medium without melatonin; IVM $+10^{-9}$ : maturation medium supplemented with $10^{-9} \mathrm{M}$ of melatonin; IVC $+10^{-9}$ : culture medium supplemented with $10^{-9} \mathrm{M}$ of melatonin; IVM/IVC $+10^{-9}$ : maturation and culture medium supplemented with $10^{-9} \mathrm{M}$ of melatonin. Fluorescence intensity in the Control group was defined as 1.0. ${ }^{a, b}$ Within the same parameter evaluated, values without a common letter differed $(p<.001)$

TAB LE 6 Total cell number and apoptotic cells (mean \pm standard deviation) in blastocysts after the addition of melatonin at $10^{-9} \mathrm{M}$ in different phases of in vitro production (Experiment 3)

\begin{tabular}{|c|c|c|}
\hline Treatment & Total cell number & $\begin{array}{l}\text { Number of } \\
\text { apoptotic cells (\%) }\end{array}$ \\
\hline $\begin{array}{l}\text { Control }^{\dagger} \\
(n=16)\end{array}$ & $135.0 \pm 7.2^{\mathrm{a}}$ & $6.5 \pm 0.6(4.8)^{b}$ \\
\hline $\begin{array}{l}\mathrm{IVM}+10^{-9} \\
(n=15)\end{array}$ & $130.6 \pm 6.7^{a}$ & $5.3 \pm 0.6(4.0)^{b}$ \\
\hline $\begin{array}{l}\text { IVC + } 10^{-9} \\
(n=18)\end{array}$ & $116.6 \pm 5.0^{a}$ & $3.0 \pm 0.5(2.5)^{a}$ \\
\hline $\begin{array}{l}\text { IVM/IVC }+10^{-9} \\
(n=15)\end{array}$ & $130.2 \pm 7.3^{\mathrm{a}}$ & $5.4 \pm 1.0(4.1)^{b}$ \\
\hline
\end{tabular}

${ }^{\dagger}$ Number of blastocysts evaluated. Control: medium without melatonin; IVM $+10^{-9}$ : maturation medium supplemented with $10^{-9} \mathrm{M}$ of melatonin; IVC $+10^{-9}$ : culture medium supplemented with $10^{-9} \mathrm{M}$ of melatonin; IVM/ IVC $+10^{-9}$ : maturation and culture medium supplemented with $10^{-9} \mathrm{M}$ of melatonin. ${ }^{a, b}$ Within a column, values without a common superscript differed among treatments $(p<.05)$.

TUNEL analysis of blastocysts (Table 4) showed a lower $(p<.05)$ number of apoptotic cells with melatonin concentration of $10^{-9} \mathrm{M}$ in the culture medium compared to the Control group.

\section{$3.3 \mid$ Experiment 3}

The effects of melatonin $\left(10^{-9} \mathrm{M}\right)$ added to maturation and/or culture medium on in vitro bovine embryonic development are shown
(Table 5). A higher blastocyst rate $(p<.05)$ was observed in IVC $+10^{-9}$ treatment compared to the Control and IVM/IVC $+10^{-9}$ groups. Additionally, the IVC $+10^{-9}$ had a greater $(p<.05)$ percentage of blastocysts Grade I.

The intracellular levels of GSH were lower $(p<.05)$ in blastocysts from the IVM $+10^{-9}$ treatment compared to the IVC $+10^{-9}$ group (Figure 3). Moreover, ROS production was higher $(p<.05)$ in the group supplemented simultaneously in the maturation and culture medium (IVM/IVC $\left.+10^{-9}\right)$.

TUNEL analysis revealed a lower $(p<.05)$ number of apoptotic cells in blastocysts produced in the IVC $+10^{-9}$ treatment (Table 6). Furthermore, the relative abundance of SOD2 mRNA was higher in the IVC $+10^{-9}$ treatment compared to the Control, as well as the heat shock protein HSPB1 compared to the IVM $+10^{-9}(p<.05$; Figure 4). The expression of genes related to cell metabolism (SLC2A1 and SLC2A3) and placentation (KRT8) was similar ( $p>.05$ ) between treatments.

\section{DISCUSSION}

Melatonin is an antioxidant molecule and can protect gametes and embryos, and we tested whether supplementing media related to the different steps during the in vitro bovine embryo production process with different concentrations of melatonin would improve the cleavage and/or the embryo quality. We showed that the addition of melatonin in the IVM or in both (IVM and IVC) consecutively is not necessary. IVC medium supplemented with $10^{-9} \mathrm{M}$ of melatonin improves embryos quality and increases the number of D7 blastocysts. Additionally, an over-expression of superoxide dismutase (SOD2) compared to the Control and HSPB1 compared to the IVM $+10^{-9}$, greater intracellular content of glutathione, and a reduction in apoptosis were observed indicative that this concentration of melatonin utilized and the in vitro production phase under the conditions described directly affected embryonic development.

In the Experiment 1, addition of melatonin to the maturation medium at concentrations of $10^{-9}\left(\mathrm{IVM}+10^{-9}\right)$ and $10^{-11} \mathrm{M}\left(\mathrm{IVM}+10^{-11}\right)$ increased cleavage rate, but did not improve blastocyst production. Also, matured oocytes of the IVM $+10^{-9}$ treatment showed a higher percentage of Grade I blastocysts, greater levels of MMP and GSH and lower ROS production compared with the IVM $+10^{-11}$ group. Maturation of bovine oocytes was improved at concentrations of $10^{-7}$ and $10^{-9} \mathrm{M}$ of melatonin, and an upregulated expression of genes associated both with oocyte maturation (GDF9, MARF1, DNMT1a) and expansion of cumulus cells (PTX3, HAS1/2) (Tian et al., 2014). Also, studies (Takeo et al., 2014; Van-Blerkom, Davis, Mathwig, \& Alexander, 2002) showed a positive relationship between MMP and matured oocytes. Moreover, high concentrations of GSH were related to increased efficiency in maturation until the time of blastocyst formation (Luberda, 2005). It is known that ROS can cause mitochondrial damage in oocytes (Ge et al., 2012), and the interaction of melatonin with ROS is a prolonged process that involves many of its metabolites, making melatonin highly effective at protecting cells against oxidative stress (Park \& Yu, 2013; Tamura et al., 2008; Van-Blerkom et al., 2002). 
FIGURE 4 Relative mRNA abundance (mean \pm standard deviation) of genes related to cell metabolism (SLC2A1, SLC2A3), oxidative stress (SOD2, HSPB1) and placentation (KRT8) in blastocysts after the addition of melatonin at $10^{-9} \mathrm{M}$ in different phases of in vitro production. Control: medium without melatonin; IVM $+10^{-9}$ : maturation medium supplemented with $10^{-9} \mathrm{M}$ of melatonin; IVC $+10^{-9}$ : culture medium supplemented with $10^{-9} \mathrm{M}$ of melatonin; IVM/IVC $+10^{-9}$ : maturation and culture medium supplemented with $10^{-9} \mathrm{M}$ of melatonin. ${ }^{\mathrm{a}, \mathrm{b}}$ Indicate differences among treatments within the same gene evaluated $(p<.05)$

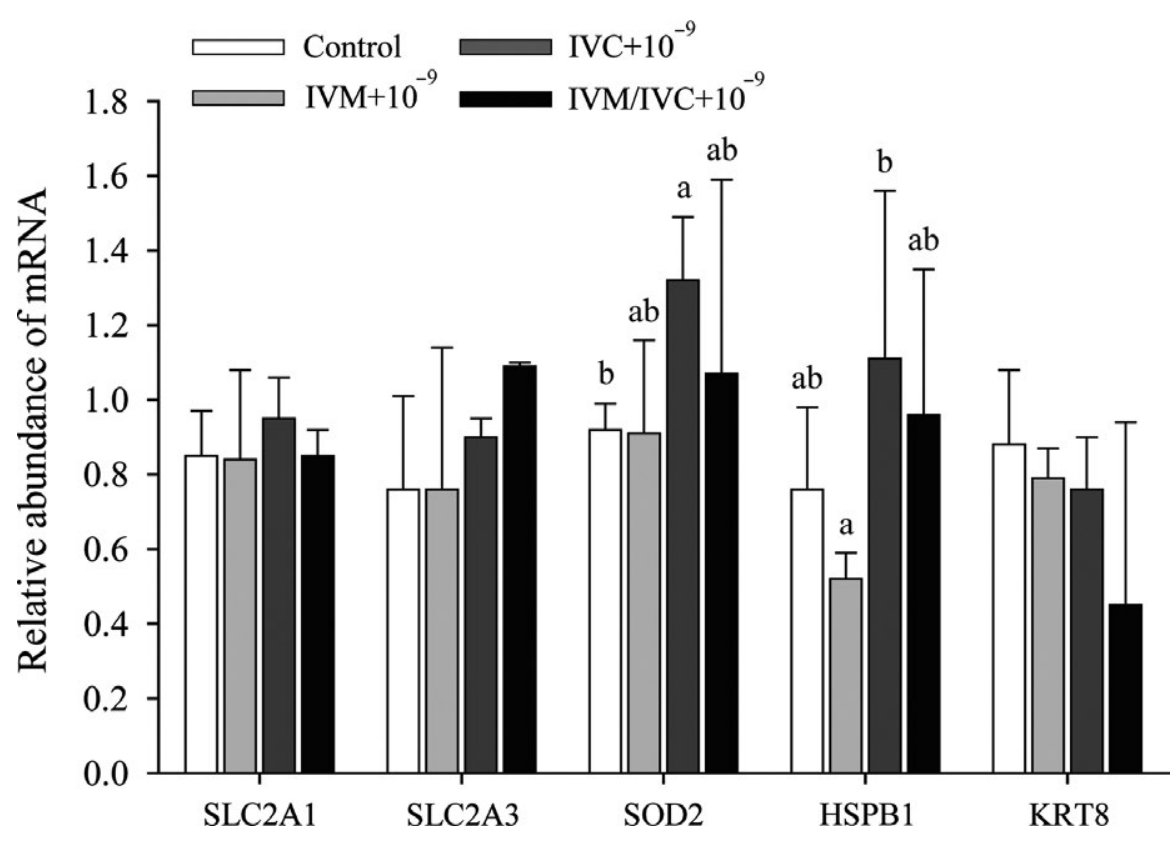

In Experiment 2, IVC $+10^{-9}$ treatment of culture media increased the percentage of high-quality blastocysts with a decreased number of apoptotic cells compared to the Control group. Furthermore, melatonin at a concentration of $10^{-11} \mathrm{M}\left(\mathrm{IVC}+10^{-11}\right)$ had a negative effect on embryo development compared to the IVC $+10^{-9}$ group. Despite melatonin improvements on in vitro oocyte maturation and embryonic development, melatonin beneficial effects appear to be speciesspecific (ovine (Abecia, Forcada, \& Zúñiga, 2002), rabbit (Mehaisen et al., 2015), porcine (Rodriguez-Osorio, Kim, Wang, Kaya, \& Memili, 2007) and mice (Tan et al., 2015)) and concentration-dependent, regardless of the therapeutic responses evaluated (e.g. antitumour activity (Zou et al., 2015), antioxidant protection (Ginther et al., 2012), enhances immune function (Srinivasan et al., 2005), sleep (Dawson \& Encel, 1993) and reproduction (Reiter et al., 2009)). Additionally, the melatonin as an antioxidant and free radical scavenger reduces the oxidative damage and dysfunction of oocytes during maturation (Casao et al., 2010; Tian et al., 2014) and embryo culture (Wang et al., 2013, 2014).

Herein, the number of apoptotic cells in blastocysts produced in vitro was used as an indicator of embryo quality (Experiments 2 and 3). Although apoptosis during pre-implantation development of the embryo plays a fundamental role in eliminating defective cells, it can also induce a greater loss of healthy cells, depending of culture conditions (Byrne, Southgate, Brison, \& Leese, 1999; Hao et al., 2003). Unlike from this study, recent reports (Sampaio, Conceição, Miranda, Sampaio, \& Ohashi, 2012; Wang et al., 2014) indicated that melatonin improves the mean cell number per blastocyst and, consequently, more cells undergoing continual mitosis that contributes to increase the potential development of the embryo (Tian et al., 2014). Moreover, there is a strong relationship of maternal melatonin with pregnancy and normal foetal development (Voiculescu, Zygouropoulos, Zahiu, \& Zagrean, 2014). The mechanisms involve the melatonin's ability to downregulate the expression of pro-apoptotic genes (p53, Bax and caspase-3) while upregulating the expression of the antioxidant enzyme (SOD and $\mathrm{Gpx} 4$ ) and the anti-apoptotic gene $\mathrm{Bcl}-2$. These changes lead a decrease in ROS production and cellular apoptosis during embryo development and consequently improve the quality of the cultured embryos (Wang et al., 2013, 2014).

In Experiment 3, the effects of an optimal melatonin concentration $\left(10^{-9} \mathrm{M}\right.$; Experiments 1 and 2$)$ added to maturation and/or culture medium were evaluated. The addition of melatonin to both maturation and culture medium (IVM/IVC $+10^{-9}$ ) resulted in a lower blastocyst rate and higher number of apoptotic cells than the group supplemented with melatonin (IVC $+10^{-9}$ ) during only the culture period. The beneficial effects of melatonin exhibit a concentration dependence (Tian et al., 2014). In development, melatonin acts by MT1 and MT2 membrane receptors that are expressed in oocytes, cumulus cells and granulosa cells (El-Raey et al., 2011; Tian et al., 2014), and its most effective concentration tested in vitro was related to presence of the MT1 melatonin receptor (Sampaio et al., 2012). Interestingly, the same report showed that only the MT1 receptor is present at the blastocyst stage indicative that melatonin has effects on oocyte maturation and embryo development via membrane receptor activation. Furthermore, most of the MT1 receptor appears in response to low concentrations of melatonin, but the response mediated by MT2 occurs at higher concentrations. Thus, some receptors may be activated during maturation but do not answer to the stimulation during the culture. At higher melatonin concentrations, a residual impact of melatonin by the MT1 receptor is seeming (Jin et al., 2003). This difference in the relative contribution of the receptor subtypes is likely not due to differences in the affinity of the receptors, but may be from differences in the levels of receptor expression or by differences in coupling to second messenger pathways (Jin et al., 2003).

We propose three hypotheses to explain the ROS increase in the IVM/IVC $+10^{-9}$ group: (i) mitochondrial dysfunction due to a failure in the methylation of DNA cytosine (Su et al., 2015); (ii) unavailability of 
membrane receptors for melatonin during culture, as receptors were occupied during maturation and or downregulated during culture and thus cease to activate important pathways (Jin et al., 2003) making it difficult to maintain redox balance; and (iii) receptor damage by ROS during embryonic development, thus minimizing the action of melatonin. The receptor damage by ROS has been observed in mice embryonic development, where melatonin modulates the sensitivity of cones, the photoreceptor cells in the retina, through activation of the MT1 and MT2 receptors (Baba et al., 2014).

Cells are also protected by an enzymatic system that includes superoxide dismutase (SOD) in addition to protection from ROS-induced oxidative damage by non-enzymatic agents (El Mouatassim, Guérin, \& Ménézo, 2000). This system transforms the superoxide radical into oxygen and hydrogen peroxide (Roy, Gauvreau, \& Bilodeau, 2008). Melatonin works via this system by scavenging free radicals, directly eliminating ROS (Galano, Tan, \& Reiter, 2013; Zhang \& Zhang, 2014), increasing the expression of genes that encode antioxidant enzymes such as SOD and GSH (Gao et al., 2012) and inhibiting the action of pro-oxidative enzymes to reduce cellular oxidative stress (Zhang \& Zhang, 2014).

Much of the cellular changes leading to thermotolerance involve genes activation of heat shock proteins as HSPB1, HSP1A1 and HSPA5 (Lepock, 2005). Under thermal stress conditions, HSPB1 acts synergistically with HSPA1 and this action is critical for preventing cell apoptosis (Showell and Conlon, 2007).

In summary, this study demonstrates the important role of melatonin during the culture phase of IVP in reducing the cellular oxidative stress and protecting blastomeres from cellular death by apoptosis. Melatonin added to culture medium at a concentration of $10^{-9} \mathrm{M}$ proved to be effective at improving the production and quality of bovine blastocysts in vitro, without the need to supplement the maturation medium sequentially in association with the culture medium These data provide additional strategies for future studies focused on optimization of IVP, cryopreservation of embryos, as well as the potential benefits of adding melatonin to the re-culture medium postthawing of cryopreserved embryos.

\section{ACKNOWLEDGEMENT}

Authors thank the Conselho Nacional de Pesquisa e Desenvolvimento Tecnologico (448904/2014, CNPq), the Fundação de Amparo a Pesquisa do Estado de Goias (CH-05/2012), Embrapa MP1 (01130600104.03.05) for the financial support, and Professor Dr. W.W. Thatcher from University of Florida for his careful revision of this paper. ML Gambarini had a scientific research grant from CNPQ.

\section{CONFLICT OF INTEREST}

The authors declare that there is no conflict of interest.

\section{AUTHOR CONTRIBUTIONS}

All the authors contributed equally to the paper.

\section{ORCID}

ML Gambarini (iD http://orcid.org/0000-0003-0517-7270

\section{REFERENCES}

Abecia, J. A., Forcada, F., \& Zúñiga, O. (2002). The effect of melatonin on the secretion of progesterone in sheep and on the development of ovine embryos in vitro. Veterinary Research Communications, 26, 151158. Retrieved from https://doi.org/10.1023/a:1014099719034

Agarwal, A., Said, T. M., Bedaiwy, M. A., Banerjee, J., \& Alvarez, J. G. (2006). Oxidative stress in an assisted reproductive techniques setting. Fertility and Sterility, 86, 503-512.

Al-Gubory, K. H., Fowler, P. A., \& Garrel, C. (2010). The roles of cellular reactive oxygen species, oxidative stress and antioxidants in pregnancy outcomes. International Journal of Biochemistry and Cell Biology, 42, 1634-1650.

Anisimov, V. N., Popovich, I. G., Zabezhinski, M. A., Anisimov, S. V., Vesnushkin, G. M., \& Vinogradova, I. A. (2006). Melatonin as antioxidant, geroprotector and anticarcinogen. Biochimica et Biophysica Acto - Bioenergetics, 1757, 573-589.

Baba, K., Benleulmi-Chaachoua, A., Journé, A.-S., Kamal, M., Guillaume, J.-L., Dussaud, S., ... Tosini, G. (2014). Heteromeric MT1/MT2 melatonin receptors modulate photoreceptor function. Science Signal, 6, 1-27. Retrieved from http://www.ncbi.nlm.nih.gov/pmc/articles/ PMC3867265/pdf/nihms536842.pdf.

Burton, G. J., \& Jauniaux, E. (2011). Oxidative stress. Best Practice \& Research Clinical Obstetrics \& Gynaecology, 25, 287-299. Retrieved from https:// doi.org/10.1016/j.bpobgyn.2010.10.016

Byrne, A. T., Southgate, J., Brison, D. R., \& Leese, H. J. (1999). Analysis of apoptosis in the preimplantation bovine embryo using TUNEL. Journal of Reproduction and Fertility, 117, 97-105.

Casao, A., Abecia, J., Cebrián-Pérez, J., Muiño-Blanco, T., Vázquez, M. I., \& Forcada, F. (2010). The effects of melatonin on in vitro oocyte competence and embryo development in sheep. Spanish Journal of Agricultural Research, 8, 35-41.

Crocomo, L. F., Marques Fillho, W. C., Landin-Alvarenga, F. C., \& Bicudo, S. D. (2012). Produção de embriões in vitro: Estresse oxidativo e antioxidantes. Veterinária e Zootecnia, 19, 470-479.

Dawson, D., \& Encel, N. (1993). Melatonin and sleep in humans. Journal of Pineal Research, 15, 1-12.

El Mouatassim, S., Guérin, P., \& Ménézo, Y. (2000). Mammalian oviduct and protection against free oxygen radicals: Expression of genes encoding antioxidant enzymes in human and mouse. European Journal of Obstetrics Gynecology and Reproductive Biology, 89, 1-6.

El-Raey, M., Geshi, M., Somfai, T., Kaneda, M., Hirako, M., Abdel-Ghaffar, A. E., ... Nagai, T. (2011). Evidence of melatonin synthesis in the cumulus oocyte complexes and its role in enhancing oocyte maturation in vitro in cattle. Molecular Reproduction and Development, 78, 250-262. Retrieved from http://www.ncbi.nlm.nih.gov/pubmed/21381146.

El-Sayed, A., Hoelker, M., Rings, F., Salilew, D., Jennen, D., Tholen, E., ... Tesfaye, D. (2006). Large-scale transcriptional analysis of bovine embryo biopsies in relation to pregnancy success after transfer to recipients. Physiological Genomics, 13, 84-96.

Eryilmaz, O. G., Devran, A., Sarikaya, E., Aksakal, F. N., Mollamahmutoğlu, L., \& Cicek, N. (2011). Melatonin improves the oocyte and the embryo in IVF patients with sleep disturbances, but does not improve the sleeping problems. Journal of Assisted Reproduction and Genetics, 28, 815-820. Retrieved from http://www.pubmedcentral.nih.gov/article render.fcgi?artid=3169684\&tool=pmcentrez\&rendertype=abstract.

Galano, A., Tan, D. X., \& Reiter, R. J. (2013). On the free radical scavenging activities of melatonin's metabolites, AFMK and AMK. Journal of Pineal Research, 54, 245-257. Retrieved from http://www.ncbi.nlm.nih.gov/ pubmed/22998574. 
Ganji, R., Nabiuni, M., \& Faraji, R. (2015). Development of mouse preantral follicle after in vitro culture in a medium containing melatonin. Cell Journal, 16,546-553. Retrieved from http://www.pubmedcentral.nih.gov/article render.fcgi?artid $=4297493 \&$ tool $=$ pmcentrez\&rendertype $=$ abstract.

Gao, C., Han, H. B., Tian, X. Z., Tan, D. X., Wang, L., Zhou, G. B., ... Liu, G. S. (2012). Melatonin promotes embryonic development and reduces reactive oxygen species in vitrified mouse 2-cell embryos. Journal of Pineal Research, 52, 305-311.

Ge, H., Tollner, T. L., Hu, Z., Da, M., Li, X., Guan, H., ... Dong, Q. (2012). Impaired mitochondrial function in murine oocytes is associated with controlled ovarian hyperstimulationand in vitro maturation. Reproduction, Fertility and Development, 24, 945-952.

Ginther, O. J., Khan, F. A., Hannan, M. A., Rodriguez, M. B., Pugliesi, G., \& Beg, M. A. (2012). Role of LH in luteolysis and growth of the ovulatory follicle and estradiol regulation of LH secretion in heifers. Theriogenology, 77, 1442-1452. Retrieved from http://www.ncbi.nlm. nih.gov/pubmed/22284221.

Gomes-Sobrinho, D. B., Oliveira, J. B. A., Petersen, C. G., Mauri, A. L., Silva, L. F. I., Massaro, F. C., ... Franco, J. G. (2011). IVF/ICSI outcomes after culture of human embryos at low oxygen tension: A meta-analysis. Reproductive Biology and Endocrinology: RB\&E, 9, 143. Retrieved from http://www.rbej.com/content/9/1/143.

Guérin, P., El Mouatassim, S., \& Ménézo, Y. (2001). Oxidative stress and protection against reactive oxygen species in the pre-implantation embryo and its surroundings. Human Reproduction Update, 7, 175-189.

Hao, Y., Lai, L., Mao, J., Im, G.-S., Bonk, A., \& Prather, R. S. (2003). Apoptosis and in vitro development of preimplantation porcine embryos derived in vitro or by nuclear transfer. Biology of Reproduction, 69, 501-507.

Holm, P., Schimidt, M. H., Greve, T., \& Callesen, H. (1999). High bovine blastocyst development in a static in vitro production system using SOFaa medium supplemented with sodium citrate and myo-inositol with or without serum-proteins. Theriogenology, 52, 683-700.

Jin, X., Von, Gall. C., Pieschl, R. L., Gribkoff, V. K., Stehle, J. H., Reppert, S. M., \& Weaver, D. R. (2003). Targeted disruption of the mouse Mel 1b melatonin receptor. Molecular and Cellular Biology, 23, 1054-1060.

Khan, S. N., Shaeib, F., Najafi, T., Kavdia, M., Gonik, B., Saed, G. M., ... Abu-Soud, H. M. (2015). Diffused intra-oocyte hydrogen peroxide activates myeloperoxidase and deteriorates oocyte quality. PLoS One, 10, e0132388. Retrieved from http://dx.plos.org/10.1371/journal. pone. 0132388 .

Kitagawa, Y., Suzuki, K., Yoneda, A., \& Watanabe, T. (2004). Effects of oxygen concentration and antioxidants on the in vitro developmental ability, production of reactive oxygen species (ROS), and DNA fragmentation in porcine embryos. Theriogenology, 62, 1186-1197.

Kwak, S.-S., Cheong, S.-A., Jeon, Y., Lee, E., Choi, K.-C., Jeung, E.-B., \& Hyun, S.-H. (2012). The effects of resveratrol on porcine oocyte in vitro maturation and subsequent embryonic development after parthenogenetic activation and in vitro fertilization. Theriogenology, 78, 86-101. Retrieved from http://www.ncbi.nlm.nih.gov/ pubmed/22445189.

Lepock, J. R. (2005). How do cells respond to their thermal environment?. International Journal of Hyperthermia, 21, 681-687.

Li, Y., Zhang, Z., He, C., Zhu, K., Xu, Z., Ma, T., ... Liu, G. (2015). Melatonin protects porcine oocyte in vitro maturation from heat stress. Journal of Pineal Research, 59, 365-375. Retrieved from https://doi.org/doi.wiley. com/10.1111/jpi.12268

Luberda, Z. (2005). The role of glutathione in mammalian gametes. Reproductive Biology, 5, 5-17.

Manjunatha, B. M., Devaraj, M., Gupta, P. S. P., Ravindra, J. P., \& Nandi, S. (2009). Effect of taurine and melatonin in the culture medium on buffalo in vitro embryo development. Reproduction in Domestic Animals = Zuchthygiene, 44, 12-16. Retrieved from http://www.ncbi.nlm.nih.gov/ pubmed/18507802.

Mehaisen, G. M. K., \& Saeed, A. M. (2013). In vitro development rate of preimplantation rabbit embryos cultured with different levels of melatonin. Zygote (Cambridge, England), 23, 111-115. Retrieved from http://www.ncbi.nlm.nih.gov/pubmed/23985360.

Mehaisen, G. M. K., Saeed, A. M., Gad, A., Abass, A. O., Arafa, M., \& El-Sayed, A. (2015). Antioxidant capacity of melatonin on preimplantation development of fresh and vitrified rabbit embryos: Morphological and molecular aspects. PLoS One, 10, e0139814. Retrieved from http://www.pubmedcentral.nih.gov/articlerender. fcgi?artid $=4595475 \&$ tool=pmcentrez\&rendertype $=$ abstract.

Mukherjee, A., Malik, H., Saha, A. P., Dubey, A., Singhal, D. K., Boateng, S., ... Malakar, D. (2014). Resveratrol treatment during goat oocytes maturation enhances developmental competence of parthenogenetic and hand-made cloned blastocysts by modulating intracellular glutathione level and embryonic gene expression. Journal of Assisted Reproduction and Genetics, 31, 229-239. Retrieved from http://www.ncbi.nlm.nih. gov/pubmed/24305840.

Park, S.-H., \& Yu, I.-J. (2013). Effect of dibutyryl cyclic adenosine monophosphate on reactive oxygen species and glutathione of porcine oocytes, apoptosis of cumulus cells, and embryonic development. Zygote (Cambridge, England), 21, 305-313. Retrieved from http://www.ncbi. nlm.nih.gov/pubmed/23171604.

Parrish, J., Krogenaes, A., \& Susko-Parrish, L. (1995). Effect of bovine sperm separation by either swim-up or percoll method on success of in vitro fertilization and early embryonic development. Theriogenology, 44, 859-869. Retrieved from http://www.ncbi.nlm.nih.gov/pubmed/ 16727781

Pfaffl, M. W. (2001). A new mathematical model for relative quantification in real-time RT-PCR. Nucleic Acids Research, 29, 2002-2007. Retrieved from http://www.ncbi.nlm.nih.gov/pubmed/11328886.

$\mathrm{R}$ Core Team (2014) R statistical software version 3.0.2. R Foundation for Statistical Computing, Vienna, AT. Retrieved from http://www.r-project.org/.

Reiter, R. J., Tan, D.-X., Manchester, L. C., Paredes, S. D., Mayo, J. C., \& Sainz, R. M. (2009). Melatonin and reproduction revisited. Biology of Reproduction, 81, 445-456. Retrieved from http://www.ncbi.nlm.nih. gov/pubmed/19439728.

Ren, L., Wang, Z., An, L., Zhang, Z., Tan, K., Miao, K., ... Tian, J. (2015). Dynamic comparisons of high-resolution expression profiles highlighting mitochondria-related genes between in vivo and in vitro fertilized early mouse embryos. Human Reproduction (Oxford, England), 30, 2892-2911. Retrieved from http://www.ncbi.nlm.nih.gov/pubmed/26385791.

Rodriguez-Osorio, N., Kim, I. J., Wang, H., Kaya, A., \& Memili, E. (2007). Melatonin increases cleavage rate of porcine preimplantation embryos in vitro. Journal of Pineal Research, 43, 283-288. Retrieved from http:// www.ncbi.nlm.nih.gov/pubmed/17803526.

Roy, M., Gauvreau, D., \& Bilodeau, J. F. (2008). Expression of superoxide dismutases in the bovine oviduct during the estrous cycle. Theriogenology, 70, 836-842.

Sampaio, R. V., Conceição, S. D. B., Miranda, M. S., Sampaio, L. D. F. S., \& Ohashi, O. M. (2012). T3 melatonin binding site, MT1 and MT2 melatonin receptors are present in oocyte, but only MT1 is present in bovine blastocyst produced in vitro. Reproductive Biology and Endocrinology, 10, 1-7. Retrieved from http://www.pubmedcentral.nih.gov/ articlerender.fcgi?artid $=3599635 \&$ tool $=$ pmcentrez\&rendertype $=a b-$ stract.

Santos, E. C. S., Sato, D., Lucia, T., \& Iwata, H. (2013). Brilliant cresyl blue staining negatively affects mitochondrial functions in porcine oocytes. Zygote, 23, 352-359. Retrieved from http://www.journals.cambridge. org/abstract_S0967199413000610.

Shi, J.-M., Tian, X.-Z., Zhou, G.-B., Wang, L., Gao, C., Zhu, S.-E., ... Liu, G.S. (2009). Melatonin exists in porcine follicular fluid and improves in vitro maturation and parthenogenetic development of porcine oocytes. Journal of Pineal Research, 47, 318-323. Retrieved from http://www. ncbi.nlm.nih.gov/pubmed/19817971.

Showell, C., \& Conlon, F. L. (2007). Decoding development in Xenopus tropicalis. Genesis, 45, 418-426. 
Srinivasan, V., Maestroni, G. J. M., Cardinali, D. P., Esquifino, A. I., Perumal, S. R. P., \& Miller, S. C. (2005). Melatonin, immune function and aging. Immunity \& Ageing, 2, 17.

Stojkovic, M., Machado, S. A., Stojkovic, P., Zakhartchenko, V., Hutzler, P., Gonçalves, P. B., \& Wolf, E. (2001). Mitochondrial distribution and adenosine triphosphate content of bovine oocytes before and after in vitro maturation: Correlation with morphological criteria and developmental capacity after in vitro fertilization and culture. Biology of Reproduction, 64, 904-909.

Su, J., Wang, Y., Xing, X., Zhang, L., Sun, H., \& Zhang, Y. (2015). Melatonin significantly improves the developmental competence of bovine somatic cell nuclear transfer embryos. Journal of Pineal Research, 59, 455-468.

Takahashi, M. (2012). Oxidative stress and redox regulation on in vitro development of mammalian embryos. The Journal of Reproduction and Development, 58, 1-9. Retrieved from http://www.ncbi.nlm.nih.gov/ pubmed/22450278.

Takeo, S., Sato, D., Kimura, K., Monji, Y., Kuwayama, T., KawaharaMiki, R., \& Iwata, H. (2014). Resveratrol improves the mitochondrial function and fertilization outcome of bovine oocytes. The Journal of Reproduction and Development, 60, 92-99. Retrieved from http://www.pubmedcentral.nih.gov/articlerender. fcgi?artid=3999399\&tool=pmcentrez\&rendertype=abstract.

Tamura, H., Takasaki, A., Miwa, I., Taniguchi, K., Maekawa, R., Asada, H., ... Sugino, N. (2008). Oxidative stress impairs oocyte quality and melatonin protects oocytes from free radical damage and improves fertilization rate. Journal of Pineal Research, 44, 280-287. Retrieved from http://www.ncbi.nlm.nih.gov/pubmed/18339123.

Tamura, H., Takasaki, A., Taketani, T., Tanabe, M., Kizuka, F., Lee, L., ... Sugino, N. (2012). The role of melatonin as an antioxidant in the follicle. Journal of Ovarian Research, 5, 5. Retrieved from http://www. pubmedcentral.nih.gov/articlerender.fcgi?artid=3296634\&tool= pmcentrez\&rendertype $=$ abstract.

Tan, K., An, L., Wang, S. M., Wang, X. D., Zhang, Z. N., Miao, K., ... Tian, J. H. (2015). Actin disorganization plays a vital role in impaired embryonic development of in vitro-produced mouse preimplantation embryos. PLoS One, 10, 1-15.

Tian, X., Wang, F., He, C., Zhang, L., Tan, D., Reiter, R. J., ... Liu, G. (2014). Beneficial effects of melatonin on bovine oocytes maturation: A mechanistic approach. Journal of Pineal Research, 57, 239-247. Retrieved from http://www.ncbi.nlm.nih.gov/pubmed/25070516.
Van-Blerkom, J., Davis, P., Mathwig, V., \& Alexander, S. (2002). Domains of high-polarized and low-polarized mitochondria may occur in mouse and human oocytes and early embryos. Human Reproduction (Oxford, England), 17, 393-406.

Vázquez, M. I., Abecia, J. A., Forcada, F., \& Casao, A. (2010). Effects of exogenous melatonin on in vivo embryo viability and oocyte competence of undernourished ewes after weaning during the seasonal anestrus. Theriogenology, 74, 618-626. Retrieved from http://www.ncbi.nlm.nih. gov/pubmed/20570337.

Voiculescu, S. E., Zygouropoulos, N., Zahiu, C. D., \& Zagrean, A. M. (2014). Role of melatonin in embryo fetal development. Journal of Medicine and Life, 7, 488-492. Retrieved from http://www.ncbi.nlm.nih.gov/ pubmed/25713608.

Wang, F., Tian, X., Zhang, L., Gao, C., He, C., Fu, Y., ... Liu, G. (2014). Beneficial effects of melatonin on in vitro bovine embryonic development are mediated by melatonin receptor 1 . Journal of Pineal Research, 56, 333-342. Retrieved from http://www.ncbi.nlm.nih.gov/ pubmed/24666110.

Wang, F., Tian, X., Zhang, L., Tan, D., Reiter, R. J., \& Liu, G. (2013). Melatonin promotes the in vitro development of pronuclear embryos and increases the efficiency of blastocyst implantation in murine. Journal of Pineal Research, 55, 267-274. Retrieved from http://www.ncbi.nlm.nih. gov/pubmed/23772689.

Zhang, H. M., \& Zhang, Y. (2014). Melatonin: A well-documented antioxidant with conditional pro-oxidant actions. Journal of Pineal Research, 57, 131-146.

Zou, D. B., Wei, X., Hu, R. L., Yang, X. P., Zuo, L., Zhang, S. M., ... Wang, Y. (2015). Melatonin inhibits the migration of colon cancer RKO cells by down-regulating myosin light chain kinase expression through crosstalk with p38 MAPK. Asian Pacific Journal of Cancer Prevention, 16, 5835-5842.

How to cite this article: Marques TC, da Silva Santos EC, Diesel TO, et al. Melatonin reduces apoptotic cells, SOD2 and HSPB1 and improves the in vitro production and quality of bovine blastocysts. Reprod Dom Anim. 2018;53:226-236.

https://doi.org/10.1111/rda.13097 